\title{
Interactions of Bombesin and Substance P at the Feline Lower Esophageal Sphincter
}

James C. Reynolds, Matthew R. Dukehart, Ann Ouyang, and Sidney Cohen

Gastrointestinal Section of the Department of Medicine, Hospital of the University of Pennsylvania, Philadelphia, Pennsylvania 19104

\begin{abstract}
The purpose of this study was to determine the interactions between bombesin and substance $P$ at the feline lower esophageal sphincter (LES). Intraluminal pressures were recorded using a fixed, perfused catheter assembly. Myoelectrical activity was recorded using bipolar Ag-AgCl serosal electrodes. Bombesin, i.v., gave a dose-dependent increase in LES pressure and electronically counted spike activity. The threshold dose was $10^{-7}$ $\mathrm{g} / \mathrm{kg}$, while the maximal dose, $10^{-5} \mathrm{~g} / \mathrm{kg}$, increased LES pressure by $65.5 \pm 14.8 \mathrm{mmHg}$. The neuroantagonist, tetrodotoxin, decreased the LES response to bombesin by $74.1 \% \pm 7.9 \%$ ( $P$ $<0.05$ ), but had no significant effect on the LES response to substance $P$. The sphincteric response to bombesin was not inhibited by bilateral cervical vagotomy, atropine, propranolol, or phentolamine $(P<0.10)$. Bombesin tachyphylaxis abolished the LES response to bombesin but had no effect on the response to substance $P$. Conversely, substance $P$ tachyphylaxis completely abolished the LES response to bombesin $(P<0.001)$. The substance $P$ antagonist [D-Pro ${ }^{2}, D-T r p^{7,9}$ substance $P$ also significantly inhibited the LES response to bombesin $(P<0.05)$. Acidification of the distal esophagus with $2.0 \mathrm{ml}$ of $0.1 \mathrm{~N} \mathrm{HCl}$ increased LES pressure by $32.5 \pm 5.2 \mathrm{mmHg}(P<0.02)$. The LES response to acid was inhibited by bombesin tachyphylaxis (maximal pressure response, $4.7 \pm 2.1 \mathrm{mmHg}, P<0.01$ compared with control acid response). The tachyphylaxis techniques were specific for the peptides giving no effect on the LES responses to phenylephrine, bethanechol, or pentagastrin. We drew the following conclusions: $(a)$ bombesin increased feline LES pressure via nonvagal neural pathways that were insensitive to adrenergic or cholinergic antagonists; $(b)$ bombesin may be involved in the enteric pathways that mediate the feline LES response to distal esophageal acidification; and (c) substance $P$ mediates the effect of bombesin at the LES and is a neurotransmitter in the LES response to acidification.
\end{abstract}

\section{Introduction}

Peptide neurotransmitters are present throughout the enteric nervous system and may play a role in the physiologic control of gastrointestinal functions. Excitatory substance $\mathbf{P}$ neurons

Address all correspondence to Dr. Reynolds, Gastrointestinal Section, Hospital of the University of Pennsylvania, 3 Dulles Building, 3400 Spruce St., Philadelphia, PA 19104. Dr. Dukehart's current address is F. Bressler Research Building, University of Maryland School of Medicine, Baltimore, MD 21202.

Received for publication 18 February 1985 and in revised form 15 October 1985

J. Clin. Invest.

(c) The American Society for Clinical Investigation, Inc.

0021-9738/86/02/0436/05 \$1.00

Volume 77, February 1986, 436-440 mediate the feline lower esophageal sphincter (LES) ${ }^{1}$ response to acidification of the distal esophagus (1). This peptidergic reflex involves tetrodotoxin-sensitive, nonvagal neural pathways that are resistant to several neurotransmitter antagonists including hexamethonium alone or in combination with atropine. The inability to identify a ganglionic transmitter in this reflex pathway using these neuroantagonists suggested the presence of other peptidergic transmitters (2) or a monosynaptic, axo-axonal response (3).

Bombesin is a tetradecapeptide that shows marked homology at the active carboxy-terminal region with several other peptides found in mammalian tissue, including gastrin-releasing peptide (4). These peptides are potent stimulants of hormone release, intestinal secretion, and gastrointestinal motility when administered centrally, intrathecally, or peripherally (5-10). Recent studies have suggested that bombesin-like peptides may act as interneuron transmitters to release substance $P$ or acetylcholine $(2,11)$. Bombesin may alter gastric motility by acting directly on smooth muscle (12) but it acts via mechanisms that are sensitive to neuroantagonists in other organ systems $(2,9,11)$. The importance of bombesin-like peptides as neurotransmitters in the enteric nervous system is also supported by immunohistochemical studies demonstrating a dense innervation of the myenteric plexus by nerves containing bombesin immunoreactive peptides $(13,14,16)$. Bombesin-like peptides have a distribution similar to that of substance $P$ and the density of both peptides is not altered by extrinsic denervation $(13,15-17)$.

The aims of this study are: to evaluate the mechanism by which bombesin increases LES pressure, to determine whether it interacts with substance $P$, and to determine whether bombesin is involved in the intrinsic reflex response of the feline LES to distal esophageal acidification. The findings indicate that bombesin may act as an interneuron transmitter at the feline LES via pathways that are independent of adrenergic or cholinergic receptors.

\section{Methods}

Studies were performed in 45 fasted cats weighing $2.4-5.8 \mathrm{~kg}$. Anesthesia was induced by ketamine hydrochloride (Ketalar; Parke, Davis \& Co., Detroit, $\mathrm{MI} ; 10.0 \mathrm{mg} / \mathrm{kg}$ i.m.) and maintained by $0.26-\mathrm{M}$ solution of chloralose in polyurethane 200 ( $0.5 \mathrm{ml}$ i.v. boluses). A tracheostomy was performed to assist ventilation using a respirator as needed. Body temperature was maintained at $37^{\circ} \mathrm{C}$ by heat lamp and monitored intraabdominally. The femoral artery and vein were cannulated to monitor blood pressure and to administer drugs.

The manometric and myoelectric recording systems have been described previously (1). Five polyvinyl catheters, $0.85 \mathrm{~mm}$ i.d., recorded intraluminal pressure from two sites in the esophagus, 3.0 and $6.0 \mathrm{~cm}$ above the mid-LES port, and at three sites in the LES, $2.0 \mathrm{~mm}$ apart, oriented $120^{\circ}$ from each other. The catheters were perfused during recording periods with deionized water at $0.76 \mathrm{ml} / \mathrm{min}$ by a low compliance,

1. Abbreviation used in this paper; LES, lower esophageal sphincter. 
pneumohydraulic infusion system (Arndorfer Medical Specialties, Greendale, WI). A sixth polyvinyl tube, $2.5 \mathrm{~mm}$ o.d., was attached to the manometric assembly to drain the stomach. Recording catheters were attached to pressure transducers and graphed on a multichannel rectilinear recorder (Beckman Instruments, Palo Alto, CA).

The manometric assembly was passed orally. The three LES ports were positioned to record maximal pressure and the apparatus was secured by a pin passed through an eyelet glued between the tubes, $1.0 \mathrm{~cm}$ aborad from the mid-LES port. The pin also secured the distal end of the LES electrode, which contained two bipolar electrodes 1.15 and $0.85 \mathrm{~cm}$ from the eyelet. This placed the two pairs of electrodes precisely between the three manometry ports and oriented transverse to the long axis of the esophagus to record circular muscle activity. The orad aspect of the electrode was secured with silk sutures.

Bipolar, Ag-AgCl electrodes also recorded myoelectrical activity from the gastric fundus, $1.0 \mathrm{~cm}$ aborad to the LES; the antrum $1.0 \mathrm{~cm}$ orad to the pylorus, and from the duodenum, $1.0 \mathrm{~cm}$ aborad from the pylorus. Electrodes were connected via a junction box to a multichannel rectilinear recorder through alternating current couplers. LES and fundic electrical recordings were made using a low frequency filter of $5.3 \mathrm{~Hz}$ and a high frequency filter of $100 \mathrm{~Hz}$. Antral, pyloric, and duodenal electrical signals were recorded using a low frequency filter of $0.16 \mathrm{~Hz}$ and a high frequency filter of $100 \mathrm{~Hz}$

Acid $(0.1 \mathrm{~N} \mathrm{HCl})$ or saline, $2.0 \mathrm{ml}$ at $37^{\circ} \mathrm{C}$, was instilled over 10.0 $s$ through the manometry port $3.0 \mathrm{~cm}$ orad to the LES. Each study was followed by a saline lavage of the same volume repeated three times to permit a return to baseline. The following drugs were used: bethanechol (Urecholine, $30 \mu \mathrm{g} / \mathrm{kg}$ ), pentagastrin (Pentavulon; Ayerst Laboratories, New York, NY; $0.5 \mu \mathrm{g} / \mathrm{kg}$ ), atropine sulfate (Vitarine, $30.0 \mu \mathrm{g} / \mathrm{kg}$ ), phentolamine mesylate (Regitine; Ciba-Geigy Corp., Pharmaceuticals Div., Summit, NJ; $2.0 \mathrm{mg} / \mathrm{kg}$ ), propranolol hydrochloride (Inderal; Ayerst Laboratories; $1.0 \mathrm{mg} / \mathrm{kg}$ ), and tetrodotoxin (Sankyo Co., Limited, Tokyo, Japan). Tetrodotoxin was given in $2.5 \mu \mathrm{g} / \mathrm{kg}$ boluses intraarterially until the LES responses to electrical vagal stimulation $(10 \mathrm{~V}, 10 \mathrm{~Hz}, 1 \mathrm{~ms})$, electrical field stimulation $(20 \mathrm{~V}, 10 \mathrm{~Hz}, 1 \mathrm{~ms})$, and balloon esophageal distension were abolished. All peptides were obtained from Peninsula Laboratories (Belmont, CA), dissolved in $0.1 \mathrm{~N}$ acetic acid, diluted in nitrogenated water titrated with $0.1 \mathrm{~N} \mathrm{NaOH}$ to raise the $\mathrm{pH}$ to 6.5-6.8, and handled in siliconized glassware (Sigmacote; Sigma Chemical Co., St. Louis, MO). The following peptides were used: substance P, [D-Pro ${ }^{2}$, D-Trp ${ }^{7,9}$ ]substance P $\left(10^{-4} \mathrm{mg} / \mathrm{kg}\right) ;\left[D-\mathrm{Arg}^{1}, \mathrm{D}^{-} \mathrm{Trp}^{7,9}\right.$, Leu $\left.^{11}\right]$ substance P $\left(5.0 \times 10^{-4} \mathrm{gm} / \mathrm{kg}\right)$; and bombesin. All drugs except for tetrodotoxin were administered as an intravenous solution. Tetrodotoxin was given as an intraarterial injection in the aorta at a site proximal to the celiac artery.

Tachyphylaxis to specific peptides was achieved by the repeated intravenous administration of a supramaximal dose of the neuropeptide $\left(10^{-4} \mathrm{gm} / \mathrm{kg}\right)$ and was confirmed by the absence of a sphincteric response to the $50 \%$ effective dose $\left(\mathrm{ED}_{s_{0}}\right)$ of that peptide. The stimulus to be tested was given when a stable baseline was established. This occurred $2.0 \pm 0.24$ min after supramaximal doses of bombesin or $4.2 \pm 0.36 \mathrm{~min}$ after substance $P(P>0.10, n=16$, and 20 respectively). Basal LES pressures were similar for control $(37.7 \pm 4.6 \mathrm{mmHg})$ and experimental $(30.9 \pm 4.1$ $\mathrm{mmHg}$ ) trials except when noted.

Bilateral cervical vagotomy was performed by transection of the nerves. Vagal nerve identification was confirmed by demonstrating LES relaxation and bradycardia in response to electrical stimulation $(10 \mathrm{~V}$, $10 \mathrm{~Hz}, 1 \mathrm{~ms}$ ). LES pressures were calculated at the mid-respiratory excursion and expressed in millimeters of mercury. Spike activity was counted using a digital electronic spike counter equipped with a voltage discriminator as previously described (1). Pyloric and antral myoelectrical activity were calculated as the percentage of pyloric slow waves with spike activity. Statistical analyses were performed using Student's $t$ test on observations made in a minimum of four animals. All data are expressed as mean \pm SE. The number of animals used in each experiment $(n)$ is noted separately.

\section{Results}

$L E S$ response to bombesin. The feline LES response to bombesin, $5 \times 10^{-7} \mathrm{~g} / \mathrm{kg}$ i.v., is shown in Fig. 1 . Bombesin produced a tonic increase in sphincter pressure and a gradual increase in spike activity over a 2-min period. The LES spike and pressure responses to increasing doses of bombesin are shown in Fig. 2. The threshold dose was $10^{-7} \mathrm{~g} / \mathrm{kg}$. The maximal increase in

Bomessin $5 \times 10^{-7} \cdot / 10$

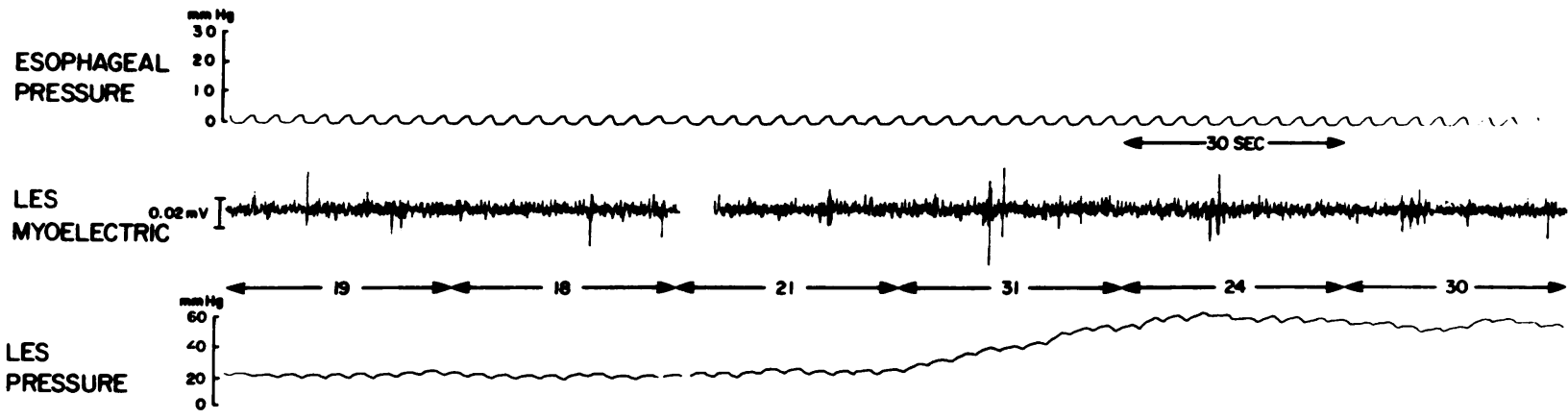

ANTRAL
MYOELECTRIC

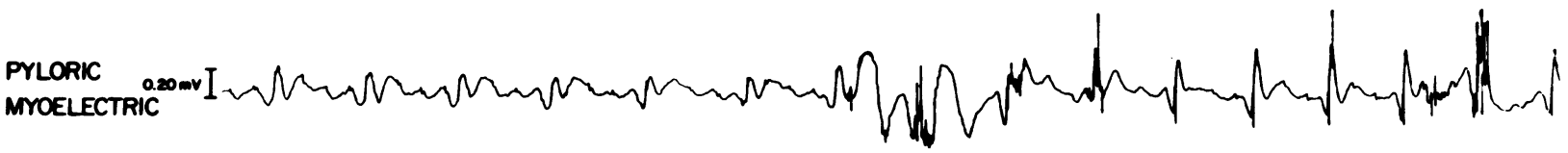

Figure 1. Myoelectrical and pressure responses of the upper gastrointestinal tract to bombesin, $5 \times 10^{-7} \mu \mathrm{g} / \mathrm{kg}$ i.v. Bombesin increased electronically counted LES spike activity (shown between arrows for each 30-s interval), LES pressure, and the percentage of pyloric slow waves with spike activity $(P<0.05)$. Bombesin had no effect on pressures recorded in the esophageal body or on antral myoelectrical activity. 


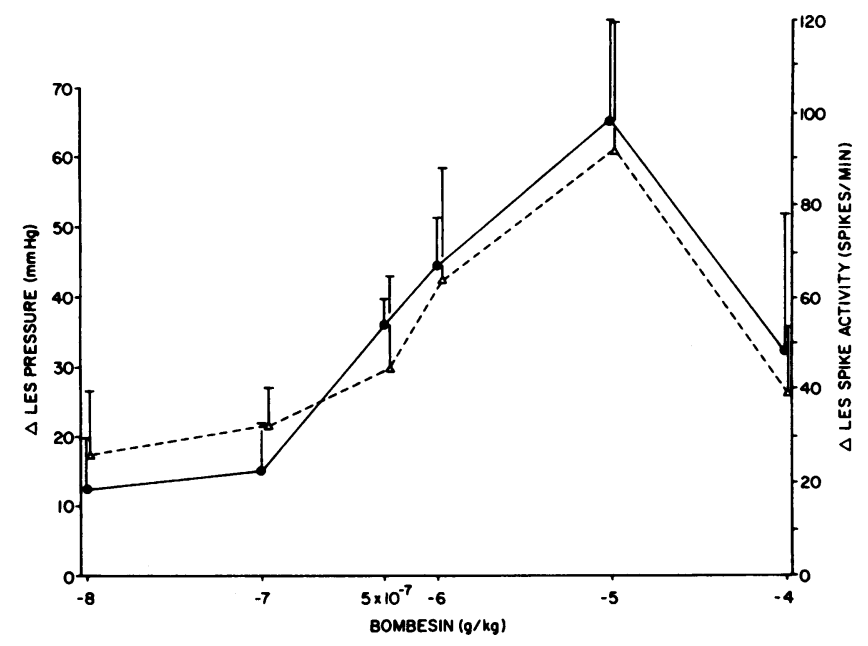

Figure 2. Dose-response curves for LES pressure (- - -) and spike activity $(---\Delta---)$ in response to increasing doses of bombesin i.v. Each point represents trials in a minimum of five animals.

sphincter pressure, $65.5 \pm 14.8 \mathrm{mmHg}$, and spike activity, $91.7 \pm 27.6 \mathrm{spikes} / \mathrm{min}$, occurred at $10^{-5} \mathrm{~g} / \mathrm{kg}$ while the $\mathrm{ED}_{50}$ dose was $5 \times 10^{-7} \mathrm{~g} / \mathrm{kg}$. LES pressure $5 \mathrm{~min}$ after the intravenous $E_{50}$ dose was equal to the peak response at this dose $(P>0.10)$. Sphincter pressure remained elevated for 15-20 min.

Bombesin, $5 \times 10^{-7} \mathrm{mg} / \mathrm{kg}$, also increased the percentage of pyloric slow waves with spike activity from $30.5 \pm 13.3 \%$ in the control period to $72.3 \geqq \mathrm{~m} 13.4 \%(P<0.05)$. Bombesin caused no consistent changes in esophageal pressure or in fundic myoelectrical activity.

Effect of antagonists or vagotomy on LES response to bombesin. The lower esophageal sphincter responses to bombesin ( 5 $\times 10^{-7} \mathrm{~g} / \mathrm{kg}$ ) before and after the neural antagonist tetrodotoxin $(25-110 \mu \mathrm{g} / \mathrm{kg}$ i.v.) are shown in Fig. 3. Tetrodotoxin decreased basal LES pressure from $27.4 \pm 6.0$ to $12.3 \pm 2.8 \mathrm{mmHg}(P=0.07$, $n=7)$. The sphincteric responses to bombesin were inhibited at all time intervals by tetrodotoxin $(P<0.05)$. The maximal increase in shincter pressure in response to bombesin $\left(5 \times 10^{-7}\right.$ $\mathrm{g} / \mathrm{kg}$ ), $59.4 \pm 18.1 \mathrm{mmHg}$, was significantly inhibited by tetrodotoxin, $10.7 \pm 4.0 \mathrm{mmHg},(P<0.05)$. The maximal LES response to substance $P\left(10^{-5} \mathrm{gm} / \mathrm{kg}\right), 89.0 \pm 26.7 \mathrm{mmHg}$, was re-
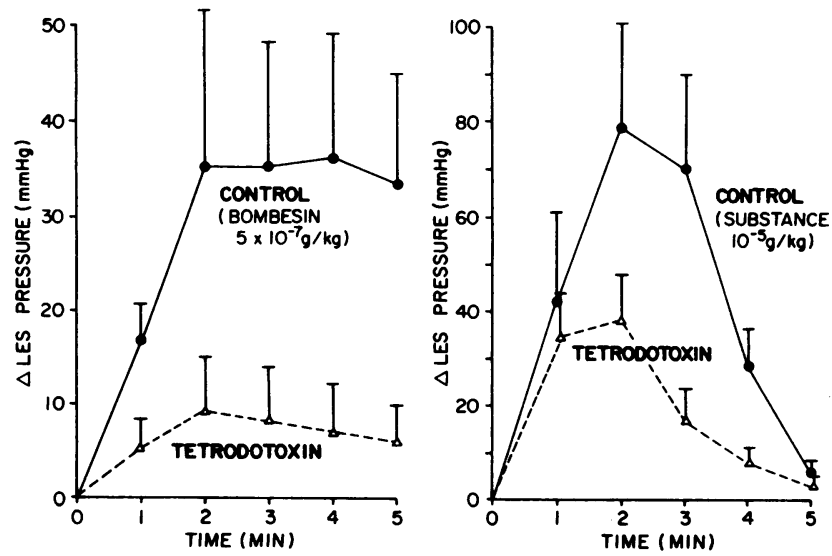

Figure 3. Effect of tetrodotoxin on the LES responses to bombesin or substance $P$. The maximal response to bombesin was inhibited by $74.1 \pm 7.9 \%(P<0.05)$, while neural blockade produced an insignificant decrease in the substance $P$ response $(P>0.10, n=8)$. duced partially to $39.9 \pm 9.1 \mathrm{mmHg}$. This change was not significant $(P>0.05, n=8)$. Atropine $(30 \mu \mathrm{g} / \mathrm{kg})$, at a dose that completely antagonized the LES response to bethanechol (30 $\mu \mathrm{g} / \mathrm{kg}$ ), had no effect on the LES response to substance $P$ (68.2 $\pm 24.4 \mathrm{mmHg}$ control vs. $65.0 \pm 21.6 \mathrm{mmHg}$ following atropine, $P>0.10, n=4)$. This dose of atropine caused an insignificant decrease in basal LES pressure $(27.0 \pm 13.7 \%$ decrease, $P>0.10)$.

The LES pressure response to bombesin, $5 \times 10^{-7} \mathrm{~g} / \mathrm{kg}$, was not inhibited by bilateral cervical vagotomy $(n=4, P>0.10)$. Atropine, $30 \mu \mathrm{g} / \mathrm{kg}$ i.v., also did not reduce the sphincteric responses to bombesin $(67.6 \pm 24.6)$ compared with the control response $(74.2 \pm 29.0, P>0.10, n=5)$.

We next investigated the LES responses to bombesin after the administration of adrenergic antagonists. Propranolol, 1.0 $\mathrm{mg} / \mathrm{kg}$, had no effect on basal LES pressure or on the LES response to bombesin $(63.7 \pm 18.2 \mathrm{mmHg}$ control vs. $96.2 \pm 26.8$ $\mathrm{mmHg}, P>0.10, n=4)$. Phentolamine reduced basal LES pressure by $61.9 \%(45.9 \pm 9.5$ to $16.8 \pm 4.3 \mathrm{mmHg}, P<0.05, n$ $=4)$ but had no effect on the lower esophageal sphincter responses to bombesin $(93.0 \pm 29.5 \mathrm{mmHg}$ vs. the control response of $63.0 \pm 9.7 \mathrm{mmHg}, P>0.10, n=5)$. Thus, the lower esophageal sphincter contractile response to bombesin is mediated by nonvagal neural pathways that are insensitive to adrenergic, or cholinergic antagonists.

LES responses following desensitization. The effect of bombesin tachyphylaxis on the LES response to the $\mathrm{ED}_{50}$ dose of bombesin $\left(5 \times 10^{-7} \mathrm{~g} / \mathrm{kg}\right.$ i.v. $)$ or substance $P$ is shown in Fig. 4 . Bombesin tachyphylaxis abolished the LES pressure and spike responses to bombesin $(P<0.005, n=7)$, but had no effect on the substance $P$ responses $(P>0.10)$. The specificity of bombesin tachyphylaxis was further examined by testing the LES responses to the $\mathrm{ED}_{50}$ doses of pentagastrin $(0.5 \mu \mathrm{g} / \mathrm{kg}$ i.v.) and bethanechol $(30.0 \mu \mathrm{g} / \mathrm{kg}$ i.v.). The control response to pentagastrin, $36.8 \pm 6.3$ $\mathrm{mmHg}$, was similar to the response following bombesin tachyphylaxis, $32.7 \pm 5.2 \mathrm{mmHg}(P>0.10, n=6)$. The LES response to bethanechol after bombesin tachyphylaxis, $63.0 \pm 16.5 \mathrm{mmHg}$, was similar to the control response, $68.8 \pm 11.5 \mathrm{mmHg}(P>0.10$, $n=5$ ).

Fig. 5 shows the effect of substance $P$ tachyphylaxis on the LES responses to the $\mathrm{ED}_{50}$ doses of substance $\mathrm{P}$ or bombesin. Densensitization of substance $P$ receptors blocked the LES response to substance $P$, as has been previously shown (1). Sub-
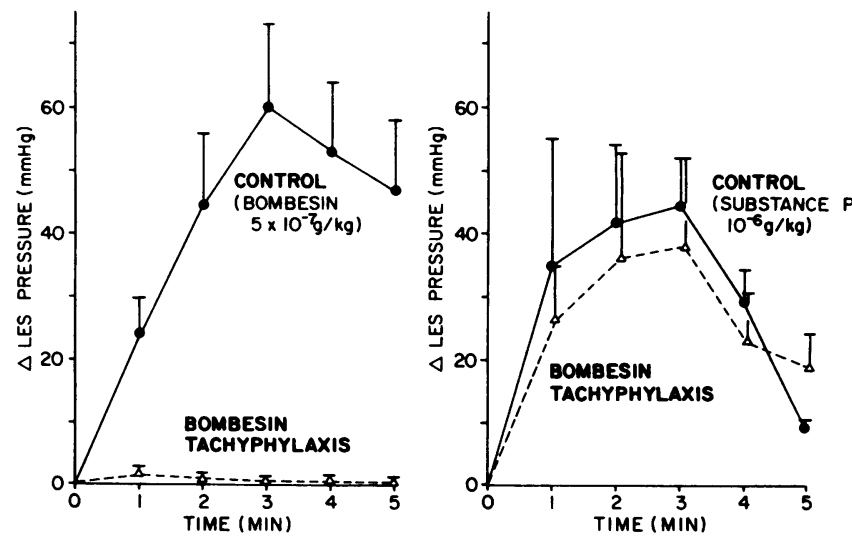

Figure 4. Effect of bombesin tachyphylaxis on the LES responses to bombesin or substance $P$. Tachyphylaxis to bombesin abolished the LES response to bombesin $(P<0.005, n=7)$ but had no effect on the LES response to substance $P(P<0.10, n=8)$. 

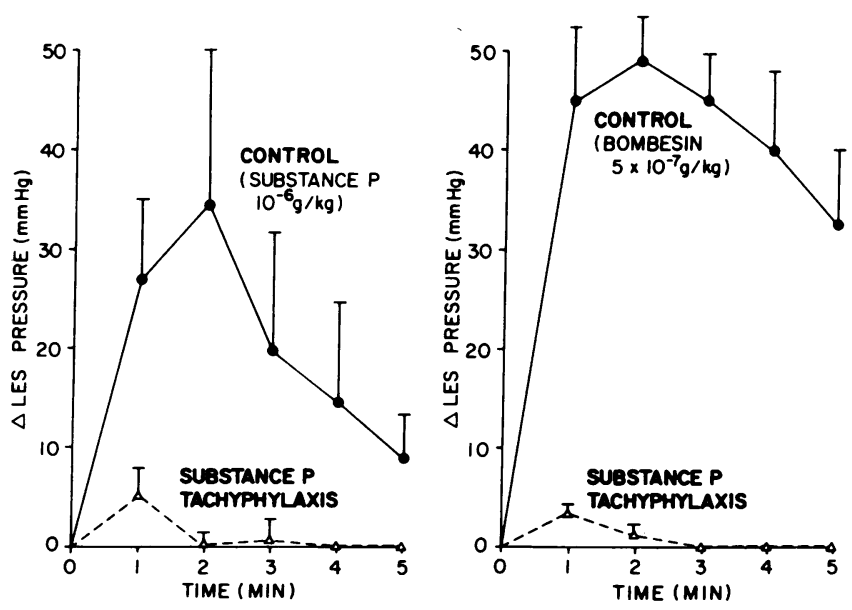

Figure 5. Effect of substance $P$ tachyphylaxis on the LES response to substance $\mathbf{P}$ or bombesin. Substance $\mathbf{P}$ tachyphylaxis inhibited the LES responses to both substance $P(P<0.01, n=5)$ and bombesin at all time intervals $(P<0.001, n=5)$.

stance $\mathrm{P}$ tachyphylaxis also completely blocked the LES response to bombesin, $3.8 \pm 1.2 \mathrm{mmHg}$, compared with control response, $54.7 \pm 5.8 \mathrm{mmHg}(P<0.001, n=5)$. Substance $P$ tachyphylaxis was specific, and showed no inhibition of the LES response to the $\mathrm{ED}_{50}$ doses of phenylephrine $(95.8 \pm 21.1 \mathrm{mmHg}$ control vs. $109.4 \pm 32.5 \mathrm{mmHg}$ following tachyphylaxis, $P>0.10, n=5$ ). Substance $\mathbf{P}$ tachyphylaxis also had no significant effect on pentagastrin stimulation of LES pressure $(P>0.10)$. The effect of substance $P$ tachyphylaxis was evaluated while LES pressure was elevated from $32.9 \pm 3.8 \mathrm{mmHg}$ in the control period to $52.5 \pm 5.7 \mathrm{mmHg}(P<0.01)$.

Effects of substance $P$ antagonists on the LES responses to bombesin. [D-Pro ${ }^{2}, \mathrm{D}-\operatorname{Trp}^{7,9}$ ]substance $\mathrm{P}$ is a weak antagonist and a partial agonist at the feline LES (1). [D-Pro ${ }^{2}$, D$\operatorname{Trp}^{7,9}$ ]substance $P\left(10^{-4} \mathrm{~g} / \mathrm{kg}\right)$ inhibited the LES pressure response to bombesin by $50.4 \pm 8.8 \%(P<0.05, n=4)$. This dose of the substance $P$ analogue is specific for substance $P$, and shows no inhibition of the LES response to phenylephrine, 151.0 \pm 24.6 $\mathrm{mmHg}$ control vs. $128.0 \pm 16.2 \mathrm{mmHg}$, following the substance $P$ analogue $(P>0.10, n=4)$. The LES response to pentagastrin is also unaffected by this substance $P$ antagonist $(P>0.10)$.

The putative substance $P$ antagonist, [D-Arg ${ }^{1}$ D-Trp ${ }^{7,9}$, Leu ${ }^{11}$ ]substance $P$ showed no inhibitory effects on the LES responses to exogenous substance $P\left(10^{-6} \mathrm{~g} / \mathrm{kg}\right)$ or to bombesin $\left(5 \times 10^{-7} \mathrm{~g} / \mathrm{kg}\right.$ i.v. $)$, even at doses up to $5 \times 10^{-4} \mathrm{~g} / \mathrm{kg}(P>0.10$, $n=6)$.

Effect of bombesin tachyphylaxis on the LES response to esophageal acidification. The LES response to distal esophageal acidification $(2.0 \mathrm{ml}, 0.1 \mathrm{~N} \mathrm{HCl})$ before and after bombesin tachyphylaxis is shown in Fig. 6. Bombesin tachyphylaxis blocked the LES responses to distal esophageal acidification at all time intervals. The maximal increase in sphincter pressure, $32.5 \pm 5.2 \mathrm{mmHg}$, was virtually abolished by bombesin tachyphylaxis, $4.7 \pm 2.0 \mathrm{mmHg}(P<0.01, n=4)$.

\section{Discussion}

The present studies indicate that a bombesin-related peptide may interact with substance $P$ to mediate physiologic responses of the feline lower esophageal sphincter. Bombesin was shown to increase sphincter pressure via nonvagal, neural pathways which were insensitive to cholinergic or adrenergic antagonists.

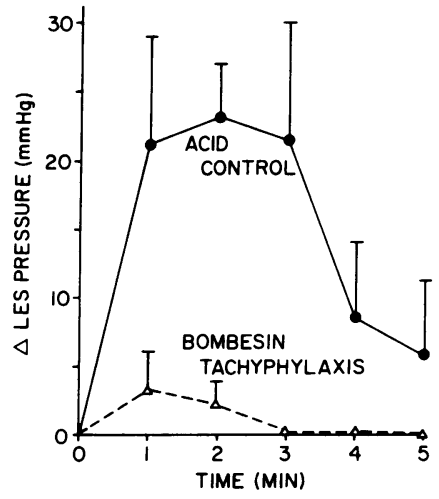

Figure 6. Acidification of the distal esophagus using $2.0 \mathrm{ml}$ of $0.1 \mathrm{~N} \mathrm{HCl}$ increased LES pressure. This response was inhibited during tachyphylaxis to bombesin $(P<0.01, n=4)$.
The interaction of substance $P$ with bombesin in increasing LES pressure was demonstrated using cross tachyphylaxis experiments as well as a putative substance $P$ antagonist. These studies further indicated that both bombesin and substance $P$ may be involved in the local neural reflex pathways that mediate the LES response to distal esophageal acidification.

Bombesin increases both LES pressure and spike activity at low doses. Bombesin is 60,000 times more potent than the cholinergic agonist, bethanechol, in contracting the feline LES. In both the present study in the cat and in a previous published study in the opossum, bombesin was shown to contract the LES through neural, tetrodotoxin-sensitive pathways (9). However, the studies in the opossum suggested that alpha adrenergic pathways sensitive to phentolamine were involved in this response. This observation was not confirmed in the cat. The role of substance $\mathbf{P}$ in mediating the response to bombesin has not been previously studied at the LES. In other species and in other muscle types, bombesin works through different mechanisms. Bombesin contracts canine gastric muscle through a direct action on the muscle (12). In smooth muscle from other organs, bombesin acts through indirect neural pathways $(2,9,11)$. In the present studies on the cat LES, careful attention was given to possible cholinergic or adrenergic pathways as suggested in these earlier publications. These differences in responses reflect differences in species and in the organ from which the smooth muscle was obtained.

In the most recent studies concerning bombesin, it has been suggested that this peptide may release substance $P$ in the guinea pig colon muscularis mucosa (2). The response of this muscle to bombesin was inhibited by desensitization of substance $P$ receptors or by the administration of substance $P$ antiserum. The feline LES response to bombesin is also antagonized by desensitization of substance $P$ receptors and by the putative substance $P$ antagonist [D-Pro ${ }^{2}, D-\operatorname{Trp}^{7,9}$ ]substance $P$. These findings indicate that bombesin and substance $P$ may interact to mediate gastrointestinal muscle contraction in several species or specific muscle types.

Bombesin and substance $P$ receptors are rapidly desensitized when repeatedly exposed to large doses of their respective agonists $(1,2,11)$. Tachyphylaxis has been shown to produce a very specific block of neuropeptide receptors in several experimental models $(18,19)$. Substance $P$ tachyphylaxis has been shown to produce inhibition of the LES to submaximal doses of the peptide, but has no effect on the sphincteric responses to phenylephrine or pentagastrin. The specificity of tachyphylaxis was also evidenced by the absence of cross tachyphylaxis to several isotypes of substance $K(1,19)$. Inhibition of the effects of bombesin by desensitization of substance $P$ receptors at the feline 
LES and guinea pig colon myenteric plexus suggests that bombesin-containing neurons innervating those structures do so via substance $P$ neurons (2). In contrast, the effect of bombesin on the canine stomach was not inhibited by substance $P$ tachyphylaxis (12).

The observation that the putative substance $P$ inhibitor, [DPro $^{2}$, D-Trp ${ }^{7,9}$ substance P, also antagonizes the effect of exogenous bombesin further suggests that substance $P$ mediates the effect of bombesin at the LES. Several studies have indicated that this substance $P$ analogue is a partial agonist and weak antagonist of substance $P(1,20,21)$. We were unable to show an inhibitory effect by [D-Arg ${ }^{1}, \mathrm{D}-\mathrm{Trp}^{7,9}$, Leu $^{11}$ ]substance $\mathrm{P}$ on the feline LES response to either substance $P$ or bombesin. This analogue has been shown to have antagonist properties in other organ systems when given in comparatively large doses. The lack of an inhibitory effect may be due to the relative low potency of this antagonist or to differences in substance $P$ receptor subtypes in different species $(4,14,21)$.

These studies do not indicate whether the interactions between substance $\mathbf{P}$ and bombesin nerves are direct or mediated by intermediate neurotransmitters. Tetrodotoxin eliminated the LES response to neural pathways activated by electrical vagal stimulation, direct field stimulation, and by balloon distension of the esophagus. While the effect of substance $P$ was unaltered in most animals, it was variably increased or inhibited in others. It is possible that this mixed response of the LES to substance $\mathbf{P}$ after tetrodotoxin represents an incomplete inhibition of intrinsic inhibitory or excitatory nerves. The partial inhibition of substance $\mathrm{P}$ by tetrodotoxin raises the possibility that its effect on LES muscle may be via interneurons and not at the neuromuscular junction. The observation that the LES response to substance $P$ or bombesin was unaffected by vagotomy or atropine suggests that neurons mediating these actions are located in the intrinsic enteric plexus.

Several immunohistochemical studies in different species have demonstrated bombesin-like immunoreactivity throughout the wall of the gastrointestinal tract with particular density in the myenteric plexus and the sphincters $(13,14,15)$. The distribution is similar to that of substance $P$ in the central nervous system and myenteric plexus $(14,17)$. This relationship provides anatomical support for these physiologic observations. The distribution of bombesin at the lower esophageal sphincter has not been investigated.

Distal esophageal acidification increased lower esophageal sphincter pressure in normal volunteers but not in patients with reflux esophagitis (22). In the cat, this response was mediated by nonvagal neural reflexes that are not inhibited by antagonists to several other types of neurotransmitters that are known to increase sphincter pressure (1). The demonstration that tachyphylaxis to two neuropeptides inhibits this response suggests that a polysynaptic reflex is involved and that peptidergic neurotransmitters may play an important role in the physiologic control of sphincter function.

\section{Acknowledgment}

The expert secretarial assistance of Mrs. S. Thornton is gratefully acknowledged.

\section{References}

1. Reynolds, J. C., A. Ouyang, and S. Cohen. 1984. A lower esophageal sphincter reflex involving substance P. Am. J. Physiol. 246(Gastrointest. Liver Physiol. 9):G346-G354.
2. Angel, F., V. L. W. Go, and J. H. Szurszewski. 1984. Innervation of the muscularis mucosae of canine proximal colon. J. Physiol. (Lond.). 357:93-108.

3. Lundberg, J. M., C-R. Martling, and A. Saria. 1983. Substance P and capsaicin-induced contractions of human bronchi. Acta. Physiol. Scand. 119:49-53.

4. Reeve, J. R., Jr., J. H. Walsh, P. Chew, B. Clark, D. Hawke, and J. E. Silver. 1983. Amino acid sequences of three bombesin-like peptides from canine intestine extracts. J. Biol. Chem. 258:5582-5588.

5. Tache, Y., and M. Brown. 1982. On the role of bombesin in homeostasis. Trends Neurosci. 5:431-433.

6. Wood, S. M., R. T. Jung, J. T. Jung, J. D. Webster, M. A. Ghatei, T. E. Adrian, N. Yanaihara, C. Yanaihara, and S. R. Bloom. 1983. The effect of the mammalian neuropeptide, gastrin-releasing peptide (GRP), on gastrointestinal and pancreatic hormone secretion in man. Clin. Sci. (Lond.). 65:365-371.

7. Poitras, P., D. Tasse, and P. LaPrise. 1983. Stimulation of motilin release by bombesin in dogs. Am. J. Physiol. 245 (Gastrointest. Liver Physiol. 8):G249-G256.

8. Porreca, F., and T. F. Burks. 1983. Centrally administered bombesin affects gastric emptying and small and large bowel transit in the rat. Gastroenterology. 85:313-317.

9. Mukhopadyay, A. K., and M. Kunnemann. 1979. Mechanism of lower esophageal sphincter stimulation by bombesin in the opossum. Gastroenterology. 76:1409-1414.

10. Corazziari, E. G., D. Fave, C. Pozzissere, A. Kohn, L. deMagistris, F. Anzini, and A. Torsoli. 1982. Effect of bombesin on lower esophageal sphincter pressure in humans. Gastroenterology. 83:10-14.

11. Fox, J. E. T., and T. J. McDonald. 1984. Motor effects of gastrinreleasing peptides and bombesin in the canine stomach and small intestine in vivo. Gastroenterology. 86:1081a. (Abstr.)

12. Mayer, E. A., J. Elashoff, and J. H. Walsh. 1982. Characterizations of the bombesin effects on canine gastric muscle. Am. J. Physiol. 243 (Gastrointest. Liver Physiol. 6):G141-G147.

13. Buffa, R., I. Solovieva, R. Fiocca, S. Giorgino, G. Rindi, E. Solcia, T. Mochizuchi, C. Yanihara, and N. Yanihara. 1982. Localization of bombesin and GRP (gastrin releasing peptide) sequences in gut nerves or endocrine cells. Histochemistry. 76:457-467.

14. Panula, P., H. Hadjiconstantinou, H. Y. Yang, and E. Costa. 1983. Immunohistochemical localization of bombesin/gastrin-releasing peptide and substance $P$ in primary sensory neuron. J. Neurosci. 3:20212029.

15. Dockray, G. J., C. Vaillant, and J. H. Walsh. 1979. The neuronal origin of bombesin-like immunoreactivity in the rat gastrointestinal tract. Neuroscience. 4:1561-1568.

16. Moghimzadch, E., R. Ekman, R. Hakanson, N. Yanaihara, and F. Sundler. 1983. Neuronal gastrin-releasing peptide in the mammalian gut and pancreas. Neuroscience. 10:553-563.

17. Costa, M., J. B. Furness, I. J. Llewellyn-Smith, and A. C. Cuello. 1981. Projections of substance P-containing neurons within the guineapig small intestine. Neuroscience. 6:411-424.

18. Lee, P. C., R. Jensen, and J. D. Gardner. 1980. Bombesin-induced desensitization of enzyme secretion in dispersed acini from guinea-pig pancreas. Am. J. Physiol. 238 (Gastrointest. Liver Physiol. 1):G213G218.

19. Zappia, L., E. Molina, M. Sianesi, and G. Bertaccini. 1978. Effects of natural analogues of substance $P$ on the motility of human gastrointestinal tract in vitro. J. Pharm. Pharmacol. 30:593-594.

20. Leander, L., R. Hakanson, S. Rosell, K. Folkers, F. Sundler, and K. Tornquist. 1981. A specific substance $P$ antagonist blocks smooth muscle contractions induced by non-cholinergic, non-adrenergic nerve stimulation. Nature (Lond.). 294:467-469.

21. Yau, W. M., and M. L. Youther. Direct evidence for a release of acetylcholine from the myenteric plexus of guinea-pig small intestine by substance P. Eur. J. Pharmacol. 81:665-668.

22. Ahtaridis, G., W. J. Snape, Jr., and S. Cohen. 1981. Lower esophageal sphincter pressure as an index of gastroesophageal acid reflux. Dig. Dis. Sci. 26:993-998. 